\title{
A Comparison of Evidence-Based Practice and the ACRL Information Literacy Standards: Implications for Information Literacy Practice
}

\author{
Nancy E. Adams
}

\begin{abstract}
Evidence-based practice (EBP), like information literacy, is concerned with an individual's knowledge, skills, and attitudes relating to using information. EBP is now a professional competency in fields as diverse as social work, nursing and allied health fields, and public policy. A comparison of the Association of College and Research Libraries' Information Literacy Competency Standards for Higher Education with the commonly accepted EBP model shows congruence, but the two models diverge in their use of authority of the producer as a marker of information quality and in their relative emphasis on formulation of the research question and application of information.
\end{abstract}

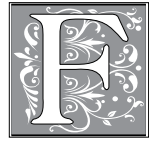

ollowing its birth in the field of medicine, many other professions have adopted the evidence-based paradigm for decision making and have incorporated skills and knowledge in evidence-based practice (EBP) as part of the educational standards for professional preparation. A cursory search of bibliographic databases will reveal publications on evidencebased practice in fields such as software engineering, librarianship, education, social work, human resources management, criminal justice, nursing, and allied health, to name a few. ${ }^{1}$ Academic librarians should become familiar with the concept of evidence-based practice because it builds on a foundation of information literacy (IL) and therefore offers an argument for increased integration of IL skills instruction into the preparatory curriculum in many disciplines. This paper examines the parallels between the frameworks of EBP and IL by comparing two of the foundational texts for each framework: User's Guides to the Medical Literature $^{2}$ by Guyatt et al. and the Association for College and Research Libraries' Information Literacy Competency Standards for Higher Education, ${ }^{3}$ hereafter referred to as the ACRL Standards.

Kaplan and Whelan have briefly mapped out the correlations between the EBP framework and the ACRL Standards to explain why librarians are involved in an EBP curriculum within a pharmacy program. ${ }^{4}$ Booth has also briefly mapped the EBP model against the ACRL Stan-

Nancy E. Adams is Associate Director, Penn State Hershey George T. Harrell Health Sciences Library; e-mail:nadams@hmc.psu.edu. (C) 2014 Nancy E. Adams, Attribution-NonCommercial (http://creativecommons.org/licenses/by-nc/3.0/) CC BY-NC 
dards to show the similarities between the two and describes one difference that will be addressed later in this paper. ${ }^{5}$ The extent of both of these authors' analyses consists of listing the "steps" of the EBP model alongside the five main points addressed by the ACRL Standards. NailChiwetalu and Ratner describe parallels between EBP and the ACRL Standards to show specific examples of how IL supports EBP in the field of speech-language pathology. ${ }^{6}$ I expand upon these comparisons to reveal nuances within the ACRL Standards' description of information literacy skills, particularly where the comparison reveals components of the EBP paradigm that are not represented in the ACRL Standards or have not been emphasized in information literacy practices of academic librarians. This is important because, if one of the goals of teaching librarians is to support student learning in various disciplines or fields of practice, then librarians must become knowledgeable about the culture, values, and information practices of those fields. Therefore, viewing the ACRL Standards through the lens of the EBP framework will reveal how the ACRL Standards serve student learning in EBP-influenced fields as measured by a construct external to the library profession. Such an analysis allows us to glean insight from other disciplines as to how our own IL practices might be improved and to elucidate ways in which academic librarians might refocus their efforts to better prepare upperlevel and graduate students studying in fields that have adopted the evidencebased paradigm.

\section{Evidence-Based Practice: Definition}

The roots of EBP are in evidence-based medicine, a paradigm that has cycled through a number of definitions but has been refined to the following: "The conscientious, explicit, and judicious use of current best evidence in making decisions about the care of individual patients."7 "Evidence" may include all types of data, ranging from observations of an individual practitioner published as a case report to published results of clinical trials found in bibliographic databases. In addition to the best available evidence, evidence-based medicine practitioners stress that each individual patient's values and each practitioner's clinical experience must also be considered in any medical decision making, acknowledging that the local clinical situation may differ from that described in published studies in subtle yet important aspects. ${ }^{8}$ As discussed later in this paper, the integration of values with the interpretation and use of information is a characteristic of EBP that is largely missing in the professional literature relating to IL and is not a prominent feature of the ACRL Standards.

After its inception in medicine in the 1980s and 1990s, other fields adopted the evidence-based framework. In nonmedical fields, it is often dubbed "evidencebased practice" (EBP) and is defined as the integration of the best available evidence with professional expertise and local values, applied to professional decision making. As stated by Citrome and Ketter, "a wide gap exists between the best evidence and the customary practice of medicine, ${ }^{\prime 9}$ but EBP affirms that the knowledge base in professional fields is rapidly expanding and encourages practitioners to use empirical evidence to make decisions rather than rely on tradition or opinion. In other words, professionals should no longer base decision making on "the way it's always been done" but should base decisions on the best available evidence, while considering how the values of the local population and one's own professional judgment might also inform the decision. In librarianship, for example, we might use studies published in the library literature to inform our decisions about using undergraduate students to provide reference desk service, while also considering feedback that has been previously gathered through user surveys about the value they place on reference services provided by our professional staff. 


\section{Comparing the EBP and Information Literacy Frameworks}

A cursory examination of the EBP literature in nonmedical fields shows that the step-by-step model for seeking and applying evidence initially proposed in evidence-based medicine has also been adopted, essentially unchanged, by other fields. ${ }^{10}$ In fact, most EBP literature, no matter the field, references the foundational texts in evidence-based medicine. Therefore, I use the framework of evidence-based medicine as described by a foundational text in that field as the basis of the comparison. Guyatt et al.'s Users' Guides to the Medical Literature: Essentials of Evidence-based Clinical Practice ${ }^{11}$ is one of the texts often used as the definitive statement of the EBP paradigm in professional literature in nonmedical fields, so I will use this text as the basis of the comparison. The Association of College and Research Libraries' (ACRL) Information Literacy Competency Standards for Higher Education ${ }^{12}$ is the foundational text I use as the defining framework for IL at the collegiate level. The ACRL Standards paint a portrait of the knowledge, skills, and attitudes that academic librarians believe are the hallmarks of an informationliterate college or university student. As described by Maura Seale, it is "the most well-known and widely-used means of conceptualizing, teaching, and assessing information literacy within higher education. ${ }^{13 "}$ The ACRL document has been extremely influential for programs and practices in academic libraries and has also influenced higher education accrediting agencies such as the Middle States Commission on Higher Education. ${ }^{14}$

It is important to note at the outset of this analysis that the ACRL Standards and the Users' Guides exist for two fundamentally different purposes: the ACRL Standards are designed as an assessment tool for the use of educators to assess learners' academic work products, ${ }^{15}$ while the Users' Guides book presents a process for practitioners to use for applying the best available scientific evidence to clinical scenarios-in effect, for making management decisions. Yet, although designed for different purposes, the two documents describe the fundamental skills needed to find, evaluate, and use information to accomplish the researchers' objective, whether that worker is a student or a practitioner. In the following pages I outline each step of the EBP process as described in the Users' Guides book and then relate that step to the ACRL Standards that describe the component IL skills that might be used in performing the step, with the assumption that readers are already familiar with the ACRL Standards. A comparison of the two frameworks reveals areas that are important to professional EBP but that are relatively overlooked by the ACRL Standards and by academic librarians in practice. Suggestions will be offered for how IL instructional practices might be changed to better prepare individuals for their futures in EBP-influenced fields.

\section{Steps in the EBP Process}

In the EBP paradigm, practitioners follow a five-step process beginning with recognition of their information need, through finding the best available evidence and applying it, and ending with a reflective assessment of the entire process. JAMAEvidence, the electronic version of the Users Guides of Guyatt et al., describes this process using the terminology AskAcquire-Appraise-Apply, a series of action verbs that show the emphasis on action steps during decision making that is characteristic of the EBP paradigm. A fifth step, Assess, will be included as well since it is often mentioned by other EBP publications including the well-known Evidence-based Medicine: How to Practice and Teach EBM. ${ }^{16}$

It is to each step of the EBP process that we now turn, comparing each to the relevant corresponding ACRL standards, outcomes, and performance indicators. The Appraise and Apply steps of EBP are mapped to the related ACRL standards, outcomes, and performance indicators 
in an appendix to this article. There are many outcomes and performance indicators in the ACRL Standards that are not immediately relevant to EBP. For example, EBP is not necessarily concerned with synthesis of new information, which is addressed in the ACRL Standards as Outcome 1.1.f.," Realizes that information may need to be constructed with raw data from primary sources." It is assumed that EBP practitioners already possess basic skills involving the interpretation and organization of information, such as "creates a system for organizing information" (ACRL Standards Outcome 2.5.b.) and "reads the text and selects main ideas" (ACRL Standards Outcome 3.1.a.).

\section{Ask: Formulate an Answerable Question}

Upon recognition of an information need relating to professional practice, practitioners who operate within the EBP paradigm must first translate their initial question into a clear and focused one that might be answered by published studies. ${ }^{17}$ In this question formulation step, the practitioner considers the four possible facets of the information need: the population; the proposed intervention, change, or treatment; the intervention, change, or treatment to which the proposed intervention should be compared; and the outcome of interest resulting from the change. An answerable question is then constructed in this population-intervention-comparison-outcome (PICO) format. For example, a question related to criminal justice might be "Do 'Scared Straight' prison tour programs deter juveniles from crime and delinquency?" which is broken down into its PICO components as illustrated in table 1 . Other question formulation models in addition to PICO have been described for nonmedical fields such as librarianship. ${ }^{18}$

When compared to an initial question such as "Do Scared Straight programs work?" the well-built question in the PICO format sets the stage for the entire EBP process. It informs the subsequent Acquire step by generating relevant search terms that could be used in electronic databases to search for evidence. It sheds light on the Appraise step by pointing to the type of study design that would best answer the question-in this case a randomized controlled trial-and by providing clear parameters for the selection of relevant research articles from a list of results generated by an electronic database search. Last, it prompts the practitioner to specify the "indicator of success," or outcome, that we would like to achieve during the Apply step..$^{19}$ In our example, we operationalize "effectiveness" as "lack of criminal record to age $18^{\prime \prime}$ and would be most interested in finding research studies that measured that outcome. Formulating a question is

\begin{tabular}{|l|l|l|}
\hline \multicolumn{3}{|c|}{ The PICO Format for Question Formulation } \\
\hline $\begin{array}{l}\text { Component of the } \\
\text { Answerable Question }\end{array}$ & Definition & Example \\
\hline $\mathbf{P}=$ Population & The user or participant & Juveniles \\
\hline I = Intervention & $\begin{array}{l}\text { The tools or treatment under } \\
\text { consideration }\end{array}$ & $\begin{array}{l}\text { Participation in Prison } \\
\text { Tours }\end{array}$ \\
\hline $\mathbf{C}=$ Comparison & $\begin{array}{l}\text { The comparison to the tool or } \\
\text { treatment under consideration, } \\
\text { which may be standard treatment or } \\
\text { "no treatment" }\end{array}$ & $\begin{array}{l}\text { No Participation in Prison } \\
\text { Tours }\end{array}$ \\
\hline $\mathbf{O}=$ Outcome & $\begin{array}{l}\text { The outcome of interest, } \\
\text { operationalized in measurable terms }\end{array}$ & $\begin{array}{l}\text { Lack of Criminal Record } \\
\text { to Age 18 }\end{array}$ \\
\hline
\end{tabular}


a crucial step, as it saves the practitioner's time and clarifies the information need..$^{20}$

The Ask step of the EBP process parallels the ACRL Standard One, which addresses how learners define their need for information: "The information literate student determines the nature and extent of the information needed." ${ }^{21}$ Outcomes in the Standards that are relevant to EBP include question formulation, identification of key concepts and terms, and modification of the initial information need so that it is of manageable size and focus. Significant research has been devoted to the question formulation step in the literature of EBP. For example, researchers have investigated the utility of PICO-based search statements for improving the recall or precision of database searches; the ability of physicians to formulate clinical questions in a PICO format; and have attempted to create a taxonomy of questions asked by physicians. ${ }^{22}$ On the other hand, there has been little published in the academic library literature that specifically treats how to teach or assess this skill; in practice, academic librarians do not often devote instructional time to skill practice relating to this standard. This is corroborated by Teresa Neely, who writes that, in academic library instruction, at least, "For college-level students, the step of defining and articulating the need for information is often underaddressed or overlooked entirely." ${ }^{23}$ She later writes, "Anecdotal evidence gathered from reference librarians reveals that many students do not know how to focus and develop their topics into something that would lend itself to enough, but not too much, research." ${ }^{24}$ One reason for the dearth of library literature relating to this standard might be that librarians are not often privy to the research process at the point in time when the research question is formulated. ${ }^{25}$ Another issue may be that college students are not often free to choose their own research topics and have never taken on the role of researcher in a real-world project for academic credit. As Kerr states of librarians' IL practices in her dissertation research, "Libraries espoused inquiry [as a pedagogical method] yet there was only little indication of inquiry methods being used in which students had opportunities to...generate their own questions."26 $^{26}$

\section{Acquire: Find the Evidence}

Once the question is formulated, EBP practitioners move to the Acquire step and locate the best available evidence to answer the question using electronic bibliographic databases or other information systems. ${ }^{27}$ A number of component skills and knowledge domains are required when acquiring evidence. The practitioner calls upon knowledge of various types of information retrieval systems and their relative comprehensiveness and ease of use. To save time, EBP practitioners also choose information resources that, in effect, perform the subsequent appraisal step for them and summarize all of the best available evidence on the problems in their field. Their selection of information resources in which to search for evidence is predicated, of course, on the resources available to them in their practice or institution. The formulation of an effective search statement that describes an information need and can be used in the information retrieval system draws from the practitioner's professional knowledge. For example, if age or exposure to a certain environmental factor have an effect on a health condition, the expert clinical searcher will know that a search term describing age or exposure should be part of the search statement or one of the limiters of the search. If classic treatments are still considered the gold standard, they will know that older literature may yet be of value. Other knowledge domains that might be drawn upon to formulate effective search statements include familiarity with the basic features and functionality of the information retrieval system; knowledge of the publishing cycle; and a knowledge of the conventions of writing in the specific field so that the search statement will contain terms that are more 
likely to occur in the title or abstract of the published evidence.

This EBP step is similar to Standard Two of the ACRL Standards: "The information literate student accesses needed information effectively and efficiently."28 Performance indicators subsumed in this standard include selection of an information retrieval system; construction of an effective search strategy and subsequent retrieval of information; and refinement of the search strategy after evaluating the relevance of the initial search results. Due to the nature of their work, academic librarians are experts at finding the evidence in the Acquire step, and this is the EBP step that we most often address and teach within our professional domain, as illustrated by the large body of professional literature addressing methods for teaching and assessing skills in information search and retrieval.

\section{Appraise: Select the Highest Quality of Evidence Available}

In the Appraise step, the acquired information must be evaluated, or critically appraised, to ascertain the "strength of evidence" offered by each article or research study. ${ }^{29}$ "Strength of evidence" is a key concept in EBP, and is a proxy for "quality," which is operationalized in the EBP model as having a high degree of internal validity - freedom from bias and error - and external validity - applicability to the question at hand. The Appraise step is the part of the EBP process that receives the most attention in teaching and assessment in medical education. ${ }^{30} \mathrm{It}$ is the Appraise step that is at the heart of why EBP is a paradigm change: no longer should professionals base their decision making on "the way we've always done it." Recognizing that much of professional practice in any field is based on opinion and tradition, the EBP paradigm seeks to change this way of thinking and advocates for decision making to be based on the strongest empirical evidence possible.

Two basic principles are at work in the Appraise step. The first is that EBP relies on empirical evidence-evidence that has been systematically tested through observation and experiment. Expert opinion-often the only information available - is not tested scientifically and therefore is considered weak evidence. Epistemologically, EBP is not suitable for disciplines where empirical evidence is not appropriate such as humanities. The second principle is that all empirical evidence is not created equal. Scientific research can offer evidence for a conclusion, and each type of research design offers relative merits and disadvantages for answering specific management questions in terms of the degree to which it elucidates a cause-and-effect relationship between two variables of interest. ${ }^{31}$ For example, a randomized controlled trial (RCT) in which participants were assigned at random to two groups, one receiving a prison tour, and one not, would be the best study design for finding out whether participation in prison tours contributes toward a lack of criminal record at age eighteen in our example. Furthermore, the strength of the evidence offered by the RCT would be increased if the study involved equal treatment of the groups in all other aspects beside the prison tour and whether the individuals who measured the outcomes of the two groups did so without knowing the group to which each participant belonged. These indicators, among others, are markers of internal validity of a scientific study. Knowledge and skills used in the Appraise step, therefore, include in-depth knowledge of the various types of study designs; identification of the study design most likely to provide the strongest evidence to answer a specific question; and recognition of the factors that affect internal validity and quality of evidence for any given study. These validity factors may vary according to discipline. Within some disciplines, including librarianship, the types of evidence that are appropriate for EBP as well as the role of quantitative versus qualitative research are contested. ${ }^{32}$ 
The Appraise step correlates with the broad ACRL Standard Three, which addresses the critical evaluation of information: "The information literate student evaluates information and its sources critically and incorporates selected information into his or her knowledge base and value system." ${ }^{33}$ A complete mapping of the Appraise step to the correlating performance indicators and outcomes under ACRL Standard Three is presented in an appendix. The outcome under this standard with which academic librarians are perhaps the most familiar is 3.2.a: "Examines and compares information from various sources in order to evaluate reliability, validity, accuracy, authority, timeliness, and point of view or bias. ${ }^{34}$ Although validity is a factor listed in the Standard, there is a divergence between the evaluative methods advanced by IL practitioners and EBP practitioners, in that librarians guide students to consider the authority of the information producer as a gauge of quality while EBP practitioners do not favor authority as a desired construct in evaluating quality.

The use of authority as a gauge of quality among academic librarians can be illustrated through a quick Google search of the phrase "evaluating information." Most of the first few dozen results link to librarian-created instructional guides that direct students to evaluate the quality of information sources by asking questions such as: What are the credentials of the author? With what institution is the author affiliated? What other publications has the individual or organization produced? This is also corroborated by Meola, who writes that the use of such web evaluation checklists often emphasizes factors external to the information such as the author's identity rather than its internal quality. ${ }^{35}$ An author's credentials are an indirect measure of the quality of his or her work and authors with pristine credentials can produce poor-quality work or work that perpetuates mainstream, unchallenged views. ${ }^{36}$ Rather than relying on the credibility or authority of the researcher(s),
EBP practitioners emphasize the degree to which a study is free from bias and error, and the degree to which it represents the strongest possible empirical evidence for the question at hand. As stated by Guyatt et al, practitioners "[place] a lower value on authority than the traditional medical paradigm." 37 Although "expert opinion" is considered to be evidence, it is at the bottom of the evidence hierarchy. Furthermore, some EBP experts say that systematic reviews, a study type that offers the highest level of evidence of all, should be designed and carried out by researchers who understand study design and statistical analysis but do not have expert knowledge of the topic at hand, to avoid introducing bias. ${ }^{38}$ An example of this is shown in the current controversy involving the United States Preventive Services Task Force's clinical guidelines for prostate cancer screening, in which the USPSTF review panel was restricted to primary care experts, precluding urologists from participating. ${ }^{39}$

\section{Apply: Use the Best Evidence Integrated with Professional Expertise and Local Values}

After appraising the evidence found and selecting the strongest available evidence that answers the question at hand, practitioners must now apply the evidence to the care of the individual patient, to management decisions, or to the development of policy. In doing so, practitioners must consider factors such as cost and feasibility of the intervention in their particular setting, whether the evidence found in the scientific studies can be generalized to their local population, and whether the benefit of the intervention is worth the cost. ${ }^{40}$ Community values and professional experience should also be brought to bear during the apply step: Is this intervention aligned with local values? Does my professional expertise suggest that the intervention is feasible? As important as evidence is, local values and professional expertise must be called upon to successfully apply that evidence 
in a given situation. For example, a 2002 Cochrane Review-considered the gold standard of systematic reviews and at the top of the evidence hierarchy-of nine controlled trials found that prison tour programs for juveniles actually increase the likelihood of delinquency among participants and are more harmful than doing nothing at all. ${ }^{41}$ In a community where prison tour programs are lauded as a model, then, the educator or juvenile case worker who decides to discontinue the program would employ professional expertise and wisdom in implementing any policy changes so that the community will understand and accept it. Similarly, suppose academic librarians find a systematic review that suggests that online instruction is just as effective as face-toface instruction for teaching undergraduate students basic library skills. ${ }^{42}$ When using this evidence to inform a service change, library staff would also consider the cost of providing online instruction compared to that of providing face-toface instruction and review preexisting local assessments of student perceptions of the quality of face-to-face instruction provided by librarians at the institution to design the most successful solution for their particular situation.

The ACRL Standard that most specifically addresses application of information is Standard Four: "The information literate student, individually or as a member of a group, uses information effectively to accomplish a specific purpose." ${ }^{43}$ (See appendix.) The purpose for which a student uses information may be for an academic work product such as a research paper, presentation, or performance at a single point in time. This differs from the EBP "work product" that is a management decision, sometimes occurring over time. Some academic librarians have operationalized the information usage competency as the students' ability to cite sources that support their points of view in papers or presentations, and assessed it as such. ${ }^{44}$ Very little literature exists on the involvement of information literacy librarians in the teaching or assessment of this standard, perhaps because the application of knowledge is construed as the domain of the subject faculty member, not the librarian. ${ }^{45}$

The EBP Apply step and the ACRL Standards both acknowledge that the practitioner/learner brings a set of professional and personal values to the informationrelated task. ACRL Standard Three subtly addresses the idea of how information use might involve community and professional values: "The information literate student...incorporates selected information into his or her knowledge base and value system." ${ }^{46}$ Performance Indicators 3.5 and 3.6 also state that the informationliterate student "...determines whether the new knowledge has an impact on the individual's value system and takes steps to reconcile differences" and "validates understanding and interpretation of the information through discourse with other individuals, subject-area experts, and/or practitioners." In the ACRL Standards, information is portrayed as value-neutral and is "incorporated" into and "impacts on" personal values, but it is the information itself that is of primary importance, not the personal values. On the other hand, the EBP Apply step explicitly calls upon the practitioner to use his or her own professional expertise and community values, not just the newly encountered information, in making management decisions. While the concept of values is present in the Standards, Harris points out that the relationship between values and information literacy is largely overlooked by IL educators in practice and that there is little guidance offered by the Standards or its accompanying guide, Objectives for Information Literacy: A Model Statement for Academic Libraries ${ }^{47}$ as to how to teach or assess learners in this area. ${ }^{48}$

\section{Assess: Evaluate How Well Evidence- Based Principles Were Applied}

The Assess step of the EBP model builds in self-assessment that can shape future uses of EBP in decision making. Booth 
describes two objectives for the Assess step in EBP for librarians and information specialists: to become better at carrying out the steps of EBP; and to assess the impact of EBP on decision making in one's practice, ${ }^{49}$ which could be extrapolated to all EBP practitioners. Sackett et al. prescribe questions to spark self-reflection for clinical practitioners as part of the Assess step. For example, when assessing performance related to question formulation, EBP practitioners should inquire of themselves, "Am I asking any...questions at all?" "Am I using a 'map' to locate my knowledge gaps and articulate questions?" "Do I have a working method to save my questions for later answering?" and "Can I get myself 'unstuck' when asking questions?" ${ }^{50}$ The Assess step engages the EBP practitioner in a continual learning process.

The Assess step of the EBP process is not neatly mirrored by an ACRL Standard. The ACRL Standards describe skills applied toward the execution of a finite task; once the task is completed, the skills described by the Standards are no longer used. Self-assessment might be part of Standard Four, which includes Outcome 4.2.b: "Reflects on past successes, failure, and alternative strategies" but this is the only description of reflection upon past performance in the ACRL Standards. ${ }^{51}$ Why do the two models diverge here? Perhaps this divergence can partly be explained by the differences in purpose of the two frameworks - the ACRL Standards describe skills and competencies required to complete an academic task, while the EBP framework describes an iterative process to guide decision making. However, given the emphasis on continual learning prevalent in fields such as medicine, where practitioners are expected to be adept at practice-based learning and improvement, ${ }^{52}$ perhaps the lack of inclusion of more explicit outcomes for self-assessment is a shortcoming of the ACRL Standards that should be rectified in future revisions of the document. It is interesting to note that one of the latest discipline-specific set of standards adopted by ACRL, the Information Literacy Standards for Teacher Education, includes a standard that explicitly addresses reflection upon process: "The information literate teacher education student evaluates... the entire information seeking process." 53 In the years between the last revision of the ACRL Standards in 2006 and the date of adoption of the Information Literacy Standards for Teacher Education in 2011, self-assessment as a learning skill may have gained increased recognition as part of the learning process. In addition, the Information Literacy Standards for Teacher Education is preparing individual learners for professional practice, perhaps to a greater extent than the ACRL Standards.

\section{A Word about ACRL Standard Five: Ethics of Information Use}

The ACRL Standards concludes with Standard Five: "The information literate student understands many of the economic, legal, and social issues surrounding the use of information and accesses and uses information ethically and legally." 54 This is the only ACRL Standard that is not represented by any of the EBP steps. Many EBP-influenced professions have codified practices governing the use of information; the confidentiality of personally identifiable health information in health care and of a students' records in education are two examples. ${ }^{55}$ However, ethicolegal and socioeconomic issues involving information such as intellectual property, copyright, and plagiarism are not directly considered in EBP. Nail-Chiwetalu and Ratner point out that EBP has an economic component, in that it requires access to electronic information, which comes at a cost. Furthermore, they claim that, once EBP practitioners are knowledgeable about the limitations of Google as a search engine for published literature in the "deep Web," the use of Google to find information for EBP could be considered unethical. ${ }^{56}$ Booth characterizes the EBP model's lack of consideration of the ethical and legal use of information as a 
deficiency of EBP, evincing an "implicit, almost naïve, assumption that information, providing that it is good enough, can simply be re-used." ${ }^{15}$

\section{Incorporating the Evidence-based Model into Information Literacy Practice}

As stated previously, many fields for which we are preparing our students have been influenced by the EBP model. Developmental aspects must be considered in making suggestions for incorporating the evidence-based model into IL practice. In the beginning of their academic preparation, students are still developing critical thinking skills and are only beginning to consider the world of research literature, let alone becoming familiar with any one field. EBP is a tool used by practitioners who are immersed in a field and familiar with the problems and information sources in that field-a situation that learners are working toward but have not yet reached and may not accomplish until they have significant practical experience. However, if academic librarians operate from the assumption that tailoring their instructional services toward students' development of IL competencies will enhance lifelong learning in students' chosen fields, then the following changes for librarians' practice that flow from this comparison of EBP and IL are suggested.

\section{Attend to Outcomes Related to Question Formulation and Application of Knowledge}

The importance that is attached to the formulation of answerable questions in the EBP literature and the relative lack of attention given to the correlate ACRL standard indicate in practice that academic librarians should give increased consideration to learners' skills in defining their information need. A promising avenue for exercising critical thinking in the formulation of research questions is problem-based learning (PBL). A major outcome of problem-based learning is the development of self-directed learning skills, which include the ability to diagnose one's own knowledge deficiencies and generate learning questions related to a case study. ${ }^{58}$ Cheney describes a collaboration between disciplinary teaching faculty and librarians in a PBL course that emphasized the question formulation step of the research process, rather than the information gathering step; she points out that this allows a focus on the reason behind the search for information, rather than a misplaced focus on informationgathering tools that is so often the case in librarian-designed instruction. ${ }^{59}$ If education is the process of learning to ask good questions, then it behooves librarians to engage students in asking the questions.

In a similar vein, the application and use of information in problem solving is identified as an important outcome in EBP-indeed, it is the entire reason for EBP-yet librarians are not often part of the teaching or assessment of how information is used in research projects. Embedded librarianship is a strategy librarians can use for integration within the Apply step of the research task. Hall describes how his experiences as an embedded librarian partnering with course faculty in a freshman speech class afforded him the opportunity to observe how students used information to support their persuasive arguments, thereby gaining insights that he used to improve his own instructional practice. ${ }^{60}$ The I-Search project is another learning activity that engages students in the entire research cycle and can be a focus of successful collaborations between librarians and course faculty ${ }^{61}$ In an I-Search project, students formulate a question of personal interest to themselves and embark on a process of searching for the answer, considering how the information found can be incorporated into their knowledge base or used in decision making, and reflect upon the process, including the successful and unsuccessful strategies they used and the emotions attendant to the process. ${ }^{62}$ The result is not a final answer to the question, but a narrative describing their question 
formulation, search for information, and application of the information.

Even if academic librarians do not teach or assess in this area, simply observing student work products, such as presentations, debates, and written projects, will serve to inform our practice by providing case studies of how students formulate questions and use information. Librarians' increased focus on helping students learn how to ask questions and use the information that they find will shed light on the entire research cycle, reveal insights that can be used in teaching the Acquire step, and better prepare students for EBP-influenced fields.

\section{Teach Ways of Evaluating Information That De-emphasize "Authority"}

As seen above, both the EBP and IL frameworks address the evaluation of the quality of information. However, the EBP model de-emphasizes expert opinion and the authority of the researcher, while, often, the practice of academic librarians is to use the authority of the information creator as a marker of quality. This is true despite the ACRL Standards inclusion of learning outcomes such as the ability to "analyze the structure and logic of supporting arguments or methods." ${ }^{63}$ Why is there a reliance on the authority of the information creator among librarians? There are several possible explanations for this discrepancy. First of all, authority and credibility are evaluative factors that librarians can easily uncover with our specialized skill set. To establish the authority of individuals or other entities we can easily Google the author's name or-even better-search for reviews of his or her books on Book Review Index Online, locate his or her biography in Who's Who, and analyze how many times his or her work has been cited using a citation index. On the other hand, the type of evaluation that EBP calls for in the Appraise step requires training in use of statistics and study design, which many librarians do not have. Even for individuals who have this training, there is no consensus on whether the practice or teaching of appraisal is appropriate for librarians in an educational context. For example, health sciences librarians in the United Kingdom, who operate in an environment deeply immersed in the evidence-based medicine paradigm, report barriers to involvement in critical appraisal instruction that largely can be attributed to lack of knowledge, lack of confidence in their own skills, and lack of ability to convince others that they are suited for this role. ${ }^{64}$ Second, academic librarians must teach students to navigate the world of information found in Google, where the bar to entry is low in terms of quality. On the other hand, the world of information encountered in EBP is already highly vetted through the peer review process as a result of publication in scholarly and professional journals, and the information creators would indeed all be judged as "authoritative" by most observers. Third, some of the information that academic librarians deal with is not quantitative, especially in humanities disciplines, and therefore is not amenable to the statistics-based evaluation that is the focus of critical appraisal in EBP. Finally, librarians' use of authority as a primary marker of quality may be an artifact of collection development policies that were created to squeeze the most value from a finite budget, and, for print formats, limited shelf space.

This comparison suggests that librarians' use of authority as a method of gauging quality glosses over considerations of methodological quality and shortchanges students by circumventing the questioning of authority, which is at the heart of the EBP paradigm. As educators, we must not be guilty of teaching that being published in a peer-reviewed journal serves as a proxy for their own independent judgment of bias and quality, or of imposing an uncritical concept of authority-including our own - on our students. This appeal to authority serves, conveniently, to buttress the librarian's own authority as an arbiter of truth and 
taste and, according to Freire's banking concept of education, rewards students' passivity rather than allowing them to become active agents. ${ }^{65}$ If we instead teach students to move beyond a surface examination of authority toward examination of the internal logic of a text, we can better equip them for evaluating the quality of information in professional practice.

\section{Limitations of This Work and Future Research}

In this article, I have outlined similarities and differences between the ACRL Standards and the EBP model, privileging the EBP model as an external standard against which to measure academic librarians' IL practices, without casting a critical gaze on EBP. With the exception of a brief discussion of EBP's lack of consideration of the legal, social, and economic issues involving information use, my gaze was restricted to viewing IL through the lens of EBP and was not reciprocal. This is a limitation of the work. Furthermore, although it is possible to step outside both frameworks to view them critically, I did not attempt to do so here. Ironically, another aspect in which EBP and the ACRL Standards are similar is that similar criticisms are directed toward each of them. ${ }^{66}$ The reader is advised to consult the critical information literacy literature for further exploration. ${ }^{67}$

Future research relative to this study is suggested. Research describing academic librarians' attitudes and instructional practices relating to the construct of authority as a marker of information quality should be undertaken. This could be done through textual analysis of librariancreated websites, tutorials, rubrics, and instructional materials describing how to evaluate the quality of information and through interviews with librarians. Also, a synthesis of the critiques of the ACRL Standards and EBP could be attempted to further map the contours of the ACRL Standards as an epistemological framework.

\section{Conclusion}

This comparison of the two foundational texts of EBP and IL to compare the two frameworks accomplishes two purposes. I have shown that the outcomes described in the ACRL Standards provide a foundation for evidence-based practice. These two frameworks mirror each other in many ways, and IL skills are highly valued by evidence-based practitioners. The skills and attitudes that academic librarians can inculcate through IL instruction are those that will prepare students to be successful in EBP-influenced professions. Second, I have suggested ways in which the EBP model, if used as an external standard by which to judge our IL instructional practices, shows gaps in the ACRL Standards or in common IL practice. Academic librarians who wish to optimally prepare their students for EBP-influenced fields would do well to teach ways to evaluate information that do not rely on authority of the information producer as an indicator of quality and to give renewed emphasis to the ACRL Standards related to question formulation and application of knowledge. In this way, students will be prepared as practitioners to ask focused and answerable questions, acquire relevant evidence and appraise its validity, apply knowledge to decision making, and self-assess their success in this process.

\section{Acknowledgement}

The author wishes to thank Greg Crawford and Russ Hall for their valuable comments during the writing of this article. 


\section{Appendix: The Appraise and Apply Evidence-based Practice Steps Correlated to ACRL Information Literacy Competency Standards for Higher Education}

\begin{tabular}{|c|c|c|c|}
\hline $\begin{array}{l}\text { Steps of the } \\
\text { EBP Process }\end{array}$ & $\begin{array}{l}\text { ACRL } \\
\text { Standard: } \\
\text { "The } \\
\text { information } \\
\text { literate } \\
\text { student..." }\end{array}$ & $\begin{array}{l}\text { ACRL } \\
\text { Performance } \\
\text { Indicator: "The } \\
\text { information } \\
\text { literate } \\
\text { student...", }\end{array}$ & ACRL Outcome \\
\hline \multirow[t]{2}{*}{$\begin{array}{l}\text { Appraise: } \\
\text { Select the } \\
\text { highest quality } \\
\text { of evidence } \\
\text { available }\end{array}$} & \multirow[t]{2}{*}{$\begin{array}{l}\text { 3. Evaluates } \\
\text { information } \\
\text { and its sources } \\
\text { critically... }\end{array}$} & $\begin{array}{l}\text { 3.2. Articulates } \\
\text { and applies } \\
\text { initial criteria for } \\
\text { evaluating both the } \\
\text { information and its } \\
\text { sources. }\end{array}$ & $\begin{array}{l}\text { 3.2.a. Examines and compares } \\
\text { information from various sources } \\
\text { to evaluate reliability, validity, } \\
\text { accuracy, authority, timeliness, } \\
\text { and point of view or bias } \\
\text { 3.2.b. Analyzes the structure and } \\
\text { logic of supporting arguments or } \\
\text { methods } \\
\text { 3.2.c. Recognizes prejudice, } \\
\text { deception, or manipulation } \\
\text { 3.2.d. Recognizes the cultural, } \\
\text { physical, or other context within } \\
\text { which the information was created } \\
\text { and understands the impact } \\
\text { of context on interpreting the } \\
\text { information }\end{array}$ \\
\hline & & $\begin{array}{l}\text { 3.4. Compares new } \\
\text { knowledge with } \\
\text { prior knowledge } \\
\text { to determine the } \\
\text { value added, } \\
\text { contradictions, } \\
\text { or other unique } \\
\text { characteristics of } \\
\text { the information. }\end{array}$ & $\begin{array}{l}\text { 3.4.a. Determines whether } \\
\text { information satisfies the research } \\
\text { or other information need } \\
\text { 3.4.b. Uses consciously selected } \\
\text { criteria to determine whether the } \\
\text { information contradicts or verifies } \\
\text { information used from other } \\
\text { sources } \\
\text { 3.4.e. Determines probable } \\
\text { accuracy by questioning the } \\
\text { source of the data, the limitations } \\
\text { of the information-gathering } \\
\text { tools or strategies, and the } \\
\text { reasonableness of the conclusions } \\
\text { 3.4.g. Selects information that } \\
\text { provides evidence for a topic }\end{array}$ \\
\hline $\begin{array}{l}\text { Apply: Use the } \\
\text { best evidence } \\
\text { integrated with } \\
\text { professional } \\
\text { expertise and } \\
\text { local values }\end{array}$ & $\begin{array}{l}3 . \ldots \\
\text { Incorporates } \\
\text { selected } \\
\text { information } \\
\text { into his or her } \\
\text { knowledge and } \\
\text { value system. }\end{array}$ & $\begin{array}{l}\text { 3.5. Determines } \\
\text { whether new } \\
\text { knowledge has } \\
\text { an impact on the } \\
\text { individual's value } \\
\text { system and takes } \\
\text { steps to reconcile } \\
\text { differences. }\end{array}$ & $\begin{array}{l}\text { 3.4.c. Draws conclusions based } \\
\text { upon information gathered } \\
\text { 3.4.f. Integrates new information } \\
\text { with previous information or } \\
\text { knowledge }\end{array}$ \\
\hline
\end{tabular}




\begin{tabular}{|c|c|c|c|}
\hline $\begin{array}{l}\text { Steps of the } \\
\text { EBP Process }\end{array}$ & $\begin{array}{l}\text { ACRL } \\
\text { Standard: } \\
\text { "The } \\
\text { information } \\
\text { literate } \\
\text { student..." }\end{array}$ & $\begin{array}{l}\text { ACRL } \\
\text { Performance } \\
\text { Indicator: "The } \\
\text { information } \\
\text { literate } \\
\text { student..." }\end{array}$ & ACRL Outcome \\
\hline \multirow{3}{*}{$\begin{array}{l}\text { Apply: Use the } \\
\text { best evidence } \\
\text { integrated with } \\
\text { professional } \\
\text { expertise and } \\
\text { local values }\end{array}$} & & & $\begin{array}{l}\text { 3.5.b. Determines whether to } \\
\text { incorporate or reject viewpoints } \\
\text { encountered }\end{array}$ \\
\hline & & $\begin{array}{l}\text { 3.6. Validates } \\
\text { understanding and } \\
\text { interpretation of } \\
\text { the information } \\
\text { through discourse } \\
\text { with other } \\
\text { individuals, } \\
\text { subject-area } \\
\text { experts, and/or } \\
\text { practitioners. }\end{array}$ & \\
\hline & $\begin{array}{l}\text { 4. Uses } \\
\text { information } \\
\text { effectively to } \\
\text { accomplish } \\
\text { a specific } \\
\text { purpose. }\end{array}$ & $\begin{array}{l}\text { 4.1. Applies } \\
\text { new and prior } \\
\text { information to } \\
\text { the product or } \\
\text { performance. }\end{array}$ & $\begin{array}{l}\text { 4.1.b. Articulates knowledge } \\
\text { and skills transferred from } \\
\text { prior experiences to planning } \\
\text { and creating the product or } \\
\text { performance } \\
\text { 4.1.c. Integrates the new and } \\
\text { prior information ...in a manner } \\
\text { that supports the purposes of the } \\
\text { product or performance }\end{array}$ \\
\hline
\end{tabular}

\section{Notes}

1. Matthew O. Howard, Paula Allen-Meares, and Mary C. Ruffolo, “Teaching Evidence-based Practice: Strategic and Pedagogical Recommendations for Schools of Social Work," Research on Social Work Practice 17, no. 5 (2007): 561-68; Robert E. Slavin, “Evidence-based Education Policies: Transforming Educational Practice and Research," Educational Researcher 31, no. 7 (2002): 15-21; Barbara A. Kitchenham, Tore Dyba, and Magne Jorgensen, "Evidence-based Software Engineering," Proceedings of the 26th International Conference on Software Engineering (2004): 273-81; Prudence W. Dalrymple, "Applying Evidence in Practice: What We Can Learn from Healthcare," Evidence-Based Library and Information Practice 5, no. 1 (2010): 43-47.

2. Gordon Guyatt, Drummond Rennie, Maureen O. Meade, and Deborah J. Cooke, Users' Guides to the Medical Literature: Essentials of Evidence-based Clinical Practice, 2nd ed. (New York: McGraw-Hill Medical, 2008).

3. Association of College and Research Libraries, Information Literacy Competency Standards for Higher Education (2000), available online at www.acrl.org/ala/mgrps/divs/acrl/standards/ standards.pdf [accessed 17 July 2012].

4. Richard B. Kaplan and Julia S. Whelan,“Buoyed by a Rising Tide: Information Literacy Sails into the Curriculum on the Currents of Evidence-based Medicine and Professional Competency Objectives," Journal of Library Administration 36, no. 1/2 (2002): 219-35.

5. Andrew Booth, "Provocative and Stimulating-But EBLIP (and Information Literacy) Are Moving Targets!" Evidence-Based Library and Information Practice 5, no. 1 (2010): 37-42.

6. Barbara J. Nail-Chiwetalu and Nan Bernstein Ratner, "Information Literacy for SpeechLanguage Pathologists: A Key to Evidence-based Practice," Language, Speech, and Hearing Services in Schools 37, no. 3 (2006): 157-67.

7. Guyatt et al., Users' Guides to the Medical Literature, 314.

8. Finlay A. McAlister, Sharon E. Straus, Gordon H. Guyatt, R. Brian Haynes, “Users' Guides 
to the Medical Literature XX: Integrating Research Evidence with the Care of the Individual Patient," JAMA: Journal of the American Medical Association 283, no. 21 (2000): 2829-36.

9. L. Citrome and T.A. Ketter, "Teaching the Philosophy and Tools of Evidence-based Medicine: Misunderstandings and Solutions," International Journal of Clinical Practice 63, no. 3 (2009): 353-59.

10. Andrew Booth and Anne Brice, Evidence-based Practice for Information Professionals: A Handbook (London: Facet, 2004); Barbara A. Kitchenham, Tore Dyba, and Magne Jorgensen, "Evidence-based Software Engineering," Proceedings of the 26th International Conference on Software Engineering (2004): 273-81; Matthew O. Howard, Paula Allen-Meares, and Mary C. Ruffolo, "Teaching Evidence-based Practice: Strategic and Pedagogical Recommendations for Schools of Social Work," Research on Social Work Practice 17, no. 5 (2007): 561-68.

11. Guyatt et al., Users' Guides to the Medical Literature.

12. Association of College and Research Libraries, Information Literacy Competency Standards.

13. Maura Seale, "Information Literacy Standards and the Politics of Knowledge Production: Using User-generated Content to Incorporate Critical Pedagogy," in Critical Library Instruction: Theories and Methods, eds. Maria T. Accardi, Emily Drabinski, and Alana Kumbier (Duluth, Minn.: Library Juice Press, 2010), 221-35.

14. Middle States Commission on Higher Education, Developing Research and Communication Skills: Guidelines for Information Literacy in the Curriculum (2003), available online at www.msche. org/publications/Developing-Skills080111151714.pdf [accessed 17 July 2012].

15. Benjamin R. Harris, "Values: The Invisible 'Ante' in Information Literacy Learning?" Reference Services Review 36, no. 4 (2008): 424-37.

16. David L. Sackett, Sharon E. Straus, W. Scott Richardson, William Rosenberg, and R. Brian Haynes, Evidence-based Medicine: How to Practice and Teach EBM (Edinburgh: Churchill Livingstone, 2003).

17. Guyatt et al., Users' Guides to the Medical Literature, 20-21.

18. Karen Sue Davies, "Formulating the Evidence Based Practice Question: A Review of the Frameworks," Evidence-Based Library and Information Practice 6, no. 2 (2011): 75-80.

19. Guyatt et al., Users' Guides to the Medical Literature, 30-31.

20. Kate Flemming,"Asking Answerable Questions," Evidence Based Nursing 1, no. 2 (1998): 36-37. 8.

21. Association of College and Research Libraries, Information Literacy Competency Standards,

22. John W. Ely, Jerome A. Osheroff, Paul N. Gorman, Mark H. Ebell, M. Lee Chambliss, Eric A. Pifer, and P. Zoe Stavri, "A Taxonomy of Generic Clinical Questions: Classification Study," British Medical Journal 321, no. 7258 (2000): 429-32; Arjen Hoogendam, Pieter F. de Vries Robbe, and A. John P. M. Overbeke, "Comparing Patient Characteristics, Type of Intervention, Control, and Outcome (PICO) Queries with Unguided Searching: A Randomized Controlled Crossover Trial," Journal of the Medical Library Association 100, no. 2 (2012): 121-26; K. Shuval, A. Shachak, S. Linn, M. Brezis, \& Reis, "Evaluating Primary Care Doctors' Evidence-based Medicine Skills in a Busy Clinical Setting," Journal of Evaluation in Clinical Practice 13, no. 4 (2007): 576-80.

23. Teresa Y. Neely, Information Literacy Assessment: Standards-based Tools and Assignments. (Chicago: American Library Association, 2006).

24. Ibid., 26.

25. Middle States Commission on Higher Education, Developing Research and Communication Skills, 23.

26. Paulette A. Kerr, Conceptions and Practice of Information Literacy in Academic Libraries: Espoused Theories and Theories-in-use [dissertation] (New Brunwsick, N.J.: Communication, Information, and Library Studies, Rutgers, The State University of New Jersey, 2010).

27. Guyatt et al., Users' Guides to the Medical Literature, 39-42.

28. Association of College and Research Libraries, Information Literacy Competency Standards, 9.

29. Guyatt et al., Users' Guides to the Medical Literature, 9.

30. Michael L. Green, "Evidence-based Medicine Training in Graduate Medical Education:

Past, Present and Future," Journal of Evaluation in Clinical Practice 6, no. 2 (2000): 121-38.

31. Guyatt et al., Users' Guides to the Medical Literature, 6-9.

32. Denise Koufogiannakis, "The Appropriateness of Hierarchies," Evidence-Based Library and Information Practice 5, no. 3 (2010): 1-3. 11.

33. Association of College and Research Libraries, Information Literacy Competency Standards,

34. Ibid.

35. Marc Meola, "Chucking the Checklist: A Contextual Approach to Teaching Undergraduates Web-Site Evaluation," portal: Libraries and the Academy 4, no. 3 (2004): 331-44.

36. Bjorn Hjorland, "Methods For Evaluating Information Sources: An Annotated Catalogue," 


\section{Implications for Information Literacy Practice 247}

Journal of Information Science 38, no. 3 (2012): 258-68.

37. Guyatt et al., Users' Guides to the Medical Literature, 6.

38. David Slawson and Alan Shaughnessy, Information Mastery: A Practical Approach to Practicing and Teaching Evidence-based Medicine [workshop], Tufts University School of Medicine, Boston, Mass., Nov. 18-20, 2010.

39. United States Preventive Services Task Force, How Did the USPSTF Arrive at This Recommendation? Frequently Asked Questions (2012), available online at www.uspreventiveservicestaskforce. org/prostatecancerscreening/prostatecancerfaq.htm [accessed 21 November 2012].

40. Guyatt et al., Users' Guides to the Medical Literature, 277.

41. Anthony Petrosino, Carolyn Turpin-Petrosino, and John Buehler, "'Scared Straight' and Other Juvenile Awareness Programs for Preventing Juvenile Delinquency," Cochrane Database of Systematic Reviews 2 (2002): CD002796.

42. Stephanie Walker, "Computer-assisted Library Instruction and Face-to-face Library Instruction Prove Equally Effective for Teaching Basic Library Skills in Academic Libraries," Evidence-based Library and Information Practice 3, no. 1 (2008): 57-60; Li Zhang, Emily M. Watson, and Laura Banfield, "The Efficacy of Computer-assisted Instruction Versus Face-to-face Instruction in Academic Libraries: A Systematic Review," Journal of Academic Librarianship 33, no. 4 (2007): 478-84. 13.

43. Association of College and Research Libraries, Information Literacy Competency Standards,

44. Caroline Cason Barratt, Kristin Nielsen, Christy Desmet, and Ron Balthazor, "Collaboration Is Key: Librarians and Composition Instructors Analyze Student Research and Writing," portal: Libraries and the Academy 9, no. 1 (2008): 37-56; Mark Emmons and Wanda Martin, "Engaging Conversation: Evaluating the Contribution of Library Instruction to the Quality of Student Research," College \& Research Libraries 63, no. 6 (2002): 545-60.

45. Neely, Information Literacy Assessment, 97. 11.

46. Association of College and Research Libraries, Information Literacy Competency Standards,

47. Instruction Section of the Association of College and Research Libraries, Objectives for Information Literacy Instruction: A Model Statement for Academic Librarians (2001), available online at www.ala.org/acrl/standards/objectivesinformation [accessed 29 June 2012].

48. Benjamin Harris, "Encountering Values: The Place of Critical Consciousness in the Competency Standards," in Critical Library Instruction: Theories and Methods, eds. Maria T. Accardi, Emily Drabinski, and Alana Kumbier (Duluth, Minn.: Library Juice Press, 2010), 279-91.

49. Andrew Booth and Anne Brice, "Evaluating Your Performance," in Evidence-based Practice for Information Professionals: A Handbook, eds. Andrew Booth and Anne Brice (London: Facet, 2004), 127-37.

50. Sackett et al., Evidence-based Medicine, 220. 13.

51. Association of College and Research Libraries, Information Literacy Competency Standards,

52. Stephen R. Hayden, Susan Dufel, and Richard Shih,"Definitions and Competencies for Practice-based Learning and Improvement," Academic Emergency Medicine 9, no. 11 (2002): $1242-48$.

53. Association for College and Research Libraries, Information Literacy Standards for Teacher Education (2011), available online at www.ala.org/acrl/sites/ala.org.acrl/files/content/standards/ ilstandards_te.pdf [accessed 19 July 2012]. 14.

54. Association of College and Research Libraries, Information Literacy Competency Standards,

55. United States Department of Health and Human Services, Summary of the HIPAA Privacy Rule (2003), available online at www.hhs.gov/ocr/privacy/hipaa/understanding/summary/privacysummary.pdf [accessed 21 November 2012]; United States Department of Education, Family Educational Rights and Privacy Act (2012), available online at http://www2.ed.gov/policy/gen/guid/ fpco/ferpa/index.html [accessed 21 November 2012]. 164.

56. Nail-Chiwetalu and Ratner, "Informational Literacy for Speech-Language Pathologists,"

57. Booth, "Provocative and Stimulating," 38.

58. Cindy E. Hmelo and Xiaodong Lin, "Becoming Self-directed Learners: Strategy Development in Problem-based Learning," in Problem-based Learning: A Research Perspective on Learning Interactions, eds. Dorothy H. Evensen and Cindy E. Hmelo (Mahwah, N.J.: L. Erlbaum Associates, 2000), 227-50.

59. Debora Cheney, "Problem-based Learning: Librarians as Collaborators and Consultants," portal: Libraries and the Academy 4, no. 4 (2004): 495-508.

60. Russell A. Hall, “The 'Embedded' Librarian in a Freshman Speech Class: Information Literacy in Action," College \& Research Libraries News 69, no. 1 (2008): 28-30. 
61. Nancy E. Adams and Jennifer K. Olivetti, “Making It Better: Library and Student Services Collaboration at Harrisburg University of Science and Technology," in Environments for Student Growth and Development: Libraries and Student Affairs in Collaboration, eds. Lisa J. Hinchliffe and Melissa A. Wong (Chicago: Association of College and Research Libraries, 2012), 52-57.

62. Julie I. Tallman and Marilyn Z. Joyce, Making the Writing and Research Connection with the I-search Process: A How-to-do-it Manual (New York: Neal-Schuman Publishers, 2006). 11.

63. Association of College and Research Libraries, Information Literacy Competency Standards,

64. Michelle Maden-Jenkins, "Healthcare Librarians and the Delivery of Critical Appraisal Training: Barriers to Involvement," Health Information E Libraries Journal 28, no. 1 (2011): 33-40.

65. James Elmborg, "Critical Information Literacy: Implications for Instructional Practice," Journal of Academic Librarianship 32, no. 2 (2006): 192-99.

66. Melanie Lazarow, "The Evidence-based Model of Information Literacy Research: A Critique," in Exploring Methods in Information Literacy Research, eds. Suzanne Lipu, Kirsty Williamson, and Annemaree Lloyd (Wagga Wagga, N.S.W.: Centre for Information Studies, Charles Sturt University, 2007), 171-83.

67. Maria Accardi, Emily Drabinski, and Alana Kumbier, Critical Library Instruction: Theories and Methods (Duluth, Minn.: Library Juice Press, 2010); Heidi L.M. Jacobs, "Information Literacy and Reflective Pedagogical Praxis," Journal of Academic Librarianship 34, no. 3 (2008): 256-62; James Elmborg, "Critical Information Literacy: Implications for Instructional Practice," Journal of Academic Librarianship 32, no. 2 (2006): 192-99. 